\title{
PENGETAHUAN DAN SIKAP ORANGTUA PENDERITA TUBERKULOSIS DALAM DETEKSI DINI TUBERKULOSIS PADA ANAK DIKECAMATAN RANCAEKEK
}

\section{KNOWLEDGE AND ATTITUDES OF PARENTS TUBERCULOSIS PATIENTS IN EARLY DETECTION OF TUBERCULOSIS CHILDREN IN CHILDREN}

\author{
Mamay Humaeroh ${ }^{1^{*}}$, Wiwi Mardiah ${ }^{2}$, Fanny Adistie $^{3}$ \\ ${ }^{1,2,3}$ Fakultas Keperawatan, Universitas Padjadjaran Jalan Raya Bandung-Sumedang Km 21 \\ Jatinangor 45363 Telp 022-84288888, email: mamayhumaeroh058@gmail.com
}

\begin{abstract}
ABSTRAK
Tuberkulosis (TB) merupakan penyakit menular. Penderita TB dewasa di wilayah kerja Puskesmas Kecamatan Rancaekek sebagian besar memiliki anak 0-14 tahun dan tinggal bersama. Deteksi dini salah satu upaya yang dapat orangtua lakukan dalam pengendalian TB anak. Faktor yang mendorong terlaksananya deteksi dini diantaranya adalah pengetahuan dan sikap. Maka dari itu penelitian ini bertujuan untuk mengidentifikasi pengetahuan dan sikap orangtua penderita TB dalam deteksi dini TB anak.

Metode penelitian menggunakan deskriptif kuantitatif. Sampel direkrut dari populasi seluruh pasien TB dewasa dengan teknik consecutive sampling menggunakan kriteria sampel orangtua penderita TB yang tinggal bersama anak 0-14 tahun dan sedang pengobatan, didapatkan dengan jumlah 78 responden. Data dikumpulkan menggunakan kuesioner yang dibuat dengan panduan dari Early Detection Of Tuberculosis dan Tuberkulosis Klinis.

Hasil penelitian menunjukkan sebagian besar responden dengan kategori pengetahuan baik $(57,7 \%)$ dan sebagian besar responden dengan sikap mendukung (56,4\%). Dapat disimpulkan bahwa sebagian besar orangtua penderita TB sudah mengetahui tentang deteksi dini dan bersikap mendukung, data dari hasil penelitian didapatkan bahwa pengalaman orangtua sebagian besar pernah mengikuti penyuluhan TB dan sudah fase pengobatan lanjutan, sehingga informasi yang di dapat lebih banyak. Namun,hasil penelitian ini belum mencakup seluruhnya orang tua penderita TB dengan kategori pengetahuan baik dan sikap mendukung terhadap deteksi dini TB anak. Diharapkan kepada petugas kesehatan dan para kader untuk meningkatkan program pendidikan kesehatan dengan memberikan pendidikan kesehatan lanjutan serta pemberian konseling.
\end{abstract}

Kata kunci : Deteksi Dini, Pengetahuan, Sikap, Tuberkulosis

\section{ABSTRACT}

Tuberculosis (TB) is a contagious disease. Adult TB patients in the work area of Puskesmas Rancaekek mostly have children 0-14 years old and live together. Early detection is one effort parents can take in TB child control. Factors that encourage the implementation of early detection include knowledge and attitude. Therefore, this study aims to identify the knowledge and attitudes of parents of TB patients in early detection of TB children.

The research used quantitative method. Samples were recruited from the population of all adult TB patients with consecutive sampling technique using sample criteria of parents of TB patients living with children 0-14 years old and on treatment, were obtained with a total of 78 
respondens. Data were collected using questionnaires made with guidelines from Early Detection of Tuberculosis and Clinical Tuberculosis.

The result of this research shows that most of respondent with good knowledge category $(57,7 \%)$ and most respondent with favorable attitude $(56,4 \%)$. It can be concluded that most parents of TB sufferers already know about early detection and supportive attitude, data from result of research found that experience of parent mostly have follow TB counseling and already phase of follow-up treatment, so that information can be more. However, the results of this study do not cover all TB patients with good knowledge category and supportive attitude toward early detection of TB children. It is expected that health workers and cadres to further improve health education programs such as home visit by providing advanced health education and counseling.

\section{Key Words : Early detection, Knowledge, Attitude, Tuberculosis}

\section{PENDAHULUAN}

Tuberkulosis (TB) yaitu jenis penyakit infeksi kronis yang merupakan penyakit penyebab kematian nomor tiga setelah penyakit jantung dan saluran pernafasan.Indonesia menempati pringkat nomor dua terbanyak jumlah penderita TB di dunia. Tahun 2015 tercatat berjumlah 330.910 penderita TB, terjadi peningkatan dari tahun sebelumnya. Dari jumlah seluruh kasus TB baru di Indonesia, Provinsi Jawa Barat merupakan pringkat tertinggi dengan kasus TB yaitu sebesar 38\% (Kemenkes RI, 2015). Angka kejadian TB dewasa terus meningkat, maka kemungkinan angka kejadian TB pada anak juga tinggi, karena anak merupakan objek yang rentan tertular penyakit TB. Hal ini dapat terjadi karena rata-rata setiap orang dewasa yang mempunyai penyakit TB dapat menularkan setidaknya 10-15 orang di lingkungannya terutama pada kelompok anakanak (Stop TB Partnership, 2015). Anak yang memiliki kontak serumah dengan penderita TB dewasa beresiko 24\%-70\% untuk terinfeksi TB dibandingkan dengan anak yang tidak memiliki kontak serumah (Kemenkes RI, 2012)

Tuberkulosis anak adalah komponen penting dalam pengendalian TB karena jumlah anak kurang dari 15 tahun adalah $40 \%-50 \%$ dari jumlah seluruh populasi dan diperkirakan setiap tahunya tercatat 550.000 anak yang menderita TB, sekitar 80.000 anak meninggal karena TB dan lebih dari 1,5 juta kasus TB anak yang belum terdiagnosa (WHO, 2015). Prevalensi pasien TB anak pada tahun 2014 di Provinsi Jawa Barat menempati pringkat tertiggi yaitu $14 \%$ per 100.000 penduduk(Kemenkes RI, 2015).

Tingginya angka TB pada anak dipengaruhi oleh berbagai faktor, diantaranya adanya kontak langsung anak dengan penderita TB dewasa, sosial ekonomi orang tua, lingkungan tempat tinggal yang padat serta sikap dan tingkat pengetahuan orang tua tentang penyakit TB (Crofton, Horne, \& Miller, 2002). Data dan informasi yang didapat dari penelitian Noviyani (2015) bahwa berdasarkan data kartu pengobatan pasien TB anak di Puskesmas Rancaekek didapatkan hasil skoring bahwa anak yang menderita TB sebagian besar memiliki keluarga atau orang tua yang memiliki riwayat TB. Didukung dengan hasil penelitian yang dilakukan oleh Loeffler (2003) bahwa 84\% sumber infeksi didapatkan dari penederita TB yang kontak serumah. TB anak yaitu terjadi pada anak usia 0-14 tahun dengan dikelompokkan pada usia 0-4 tahun dan 5-14 tahun. TB pada anak sulitnya dalam mendiagnosa karena anak sulit untuk dilakukan pemeriksaan dahak sehingga terdapat banyak kasus TB anak yang belum terlaporkan dan belum mendapatkan penatalaksanaan yang sesuai dengan ketentuan DOTS. Sehingga akan memberikan dampak negatif terhadap morbiditas dan mortalitas anak (Kemenkes RI, 2013).

Di Kabupaten Bandung fasilitas dan sarana kesehatan relatif cukup banyak. Pelayanan kesehatan milik pemerintah yaitu Puskesmas sudah terdapat di setiap Kecamatan sehingga dapat menjangkau ke seluruh desa. Idealnya dengan fasilitas tersebut kejadian TB dapat terselesaikan dan 
dicegah penyebarannya. Namun pada kenyataannya kasus TB masih banyak terjadi di masyarakat. Menurut data sekunder Kabupaten Bandung dengan angka kejadian seluruh jumlah kasus TB yaitu 5.342 per 100.000 penduduk yang merupakan peringkat tertinggi dan kasus TB paru pada anak dengan angka kajadian 1.390 per 100.000 penduduk (Dinkes Provinsi Jawa Barat, 2015). Menurut petugas Dinas Kesehatan Kabupaten Bandung penderita TB terbanyak terdapat di wilayah Kecamatan Rancaekek.

Kecamatan Rancaekek memiliki tiga Puskesmas, yaitu Puskesmas Rancaekek, Puskesmas Linggar dan Puskesmas Nanjung Mekar. Masing-masing puskesmas telah memiliki program DOTS dalam penanggulangan penyakit TB. Menemukan dan menyembuhkan pasien TB adalah cara terbaik untuk memutus rantai penularan penyakit terutama pada kelompok yang rentan yaitu kelompok anak-anak. Akan tetapi berdasarkan data pasien TB anak dari tiga puskesmas tersebut didapatkan data bahwa sebagian besar pasien anak yang menderita TB tinggal bersama keluarga yang memiliki riwayat TB.

Menurut data kasus TBdari tiga Puskesmas di Rancaekek tahun 2015 tercatat sebanyak 350 penderita TB dewasa dan 104 penderita TB anak. Kemudian kasus TB pada tahun 2016 tercatat sebenyak 425 penderita TB dewasa dan 97 penderita TB anak. Melihat jumlah data pasien tersebut walaupun data TB anak mengalami penurunan dari tahun sebelumnya namun penderita TB dewasa mengalami peningkatan dari tahun sebelumnya, dengan hal ini maka risiko penularan TB terhadap anak juga tinggi. Menurut data dan informasi dari hasil penelitian Noviyani, Fatimah, Nurhidayah dan Adistie (2015) tentang upaya pencegahan penularan TB dari dewasa terhadap anak di puskesmas DTP Rancaekek di dapatkan hasil bahwa dengan seluruh responden 54 pasien $100 \%$ tidak mendukung pencegahan penularan TB terhadap anak.

Berdasarkan penelitian di Afrika menurut Guwatudde (2003) TB anak merupakan bagian dari penyakit keluarga, karena pada umumnya TB terjadi didalam lingkungan rumah tangga. Maka dari itu upaya deteksi dini TB pada anak harus dimiliki oleh keluarga ataupun orang tua, sehingga penularan penyakit dan dampak negatif yang akan terjadi pada anak dapat dicegah. Deteksi dini merupakan salah satu tindakan dalam pencegahan sekunder yang bertujuan untuk mencegah terjadinya penyakit dan mencegah keparahan penyakit. Upaya deteksi dini TB dapat dilakukan oleh orang tua yaitu dengan cara mengenali tanda gejala TB anak, mengetahui bagaimana cara penulran TB dan faktor risiko terhadap penularan TB anak (WHO, 2011).

Tanda gejala yang harus di curigai ketika anak terinfeksi tuberkulosis paru, menurut Crofton, Horne dan Miller (2002) meliputi berat badan turun selama lebih dari 4 minggu atau tidak bertambah dalam 1 bulan meskipun sudah mendapatkan penanganan gizi yang baik, terlihat lemas dan letih sehingga tidak mampu melakukan kegiatan seperti biasanya, sering berkeringat terutama pada malam hari, batuk menetap disertai mengi atau wheezing sesekali batuk menyerupai batuk rejan atau kering sehingga sulit untuk mengeluarkan sputum atau dahak, demam dan meriang selama lebih dari 1 minggu, tidak nafsu makan (anoreksia), terasa sesak dan dada terasa nyeri. Faktor resiko kejadian TB pada anak yakni adanya riwayat kontak dengan penderita, vaksinasi $B C G$, riwayat kehamilan ibu dengan $T B$, kepadatan lingkungan, ventilasi yang kurang baik, malnutrisi dan banyak terdapat pasien TB dewasa aktif di sekitar lingkungan tempat tinggal. Selain itu, menurut Ajis, Mulyani dan Pramono (2009), anak usia di bawah lima tahun mempunyai risiko lebih besar mengalami progresi infeksi penyakit TB karena imunitas yang masih rendah atau belum berkembang sempurna, risiko terkena penyakit TB pada bayi sebesar $43 \%$, usia 1-5 tahun sebesar $24 \%$, usia remaja $15 \%$ dan dewasa $5-10 \%$. Selain itu, mengetahui cara penularan juga merupakan bagian dari deteksi dini, cara penularan TB paru pada anak yaitu dengan melalui udara, melalui batuk dari penderita TB orang dewasa, pada saat orang dewasa batuk sejumlah tetesan cairan (ludah) tersembur ke udara. Apabila orang tersebut menderita TB paru, maka percikan dahak tersebut akan mengandung kuman, kemudian terhirup oleh anak. 
Menurut Shalihahesfi (2013) faktor yang melatarbelakangi orang tua tidak membawa anaknya ke pelayanan kesehatan salah satunya yaitu faktor pengetahuan orang tua terhadap TB. Berdasarkan hasil penelitian Sudiantara, Wahyuni dan Harini (2014) bahwa faktor-faktor yang mendukung kejadian TB paru dari 34 responden yaitu faktor predisposisi $(44 \%)$, faktor pendukung (32\%) dan faktror pendorong (24\%). Faktor predisposisi dapat terwujud dalam pengetahuan, sikap, kepercayaan dan nilainilai yang dimiliki oleh masyarakat.

Berdasarkan data awal tindakan preventif yang dilakukan dari masing-masing puskesmas di Kecamatan Rancaekek yaitu dengan melaksanakan program imunisasi BCG, cakupan imunisasi BCG sudah mencapai $100 \%$ dan memperhatian status gizi anak dengan diadakannya program posyandu di setiap bulan. Selain itu, pemberian pendidikan kesehatan terhadap pasien TB telah diberikan oleh petugas kesehatan ketika pasien melakukan kontrol dan pengobatan ke Puskesmas, akan tetapi pendidikan lanjutan dan kunjungan rumah belum sepenuhnya terlaksanakan terutama kepada penderita yang memiliki anak usia 0-14 tahun dan tinggal bersama, karena berisiko tinggi anak tertular dari orang tuanya. Sedangkan orang tua berperan dalam menjaga kesehatan anaknya, maka dari itu pengetahuan dan sikap terhadap deteksi dini harus dimiliki orang tua terutama yang menderita TB.

Hasil studi pendahuluan kepada 6 orang tua yang berkunjung ke Puskesmas, 4 orang tua mengatakan sudah mengetahui tentang TB namun hanya 3 orang tua yang dapat menyebutkan salah satu faktor risiko, cara penularan dan tanda gejala. Salah satu orang tua mengaku mengetahui tentang TB karena hasil dari mengikuti penyuluhan yang dilakukan oleh petugas kesehatan dan kader setempat. Menurut salah satu kader setempat, sebagian warga tidak membawa anaknya ke pelayanan kesehatan untuk dilakukan pemeriksaan TB walaupun telah dicurigai anak terkena TB karena adanya anggota keluarga yang mempunyai TB tinggal bersama anak tersebut, hal tersebutdapat dipengeruhi oleh pengetahuan dan sikap orang tua tersebut terhadap deteksi dini TB. Menurut hasil penelitian yang dilakukan
Manalu dan Sukana (2011) yang dilakukan di wilayah kerja Puskesmas Stapan Tanggerang dengan metode kualitatif dengan 3 kelompok (Bapak, Ibu dan Remaja) dengan hasil simpulan bahwa setelah seseorang mengetahui tentang gejala dan tanda terkena TB sebagian besar seseorang tersebut segera melakukan deteksi dini seperti langsung mencari informasi dan pengobatan apakah itu sifatnya konsultasi atau pemeriksaan langsung. Kemudian hasil penelitian Bati, Legesse dan Medhin (2013) sebagian besar responden (94,3\%) diantaranya telah mendengar tentang TB, namun yang mengetahui gejala dengan nyeri dada $(30,8 \%)$, penurunan berat badan $(14,7 \%)$ dan batuk selama 2 minggu lebih $(9,9 \%)$, selain itu hasil pnelitian tersebut mencacat rendahnya tingkat pengetahuan tentang faktor risiko dan sikap yang kurang terhadap TB.

Berdasarkan data diatas, hal ini menjadi penting bagi peneliti untuk mengetahui bagaimana gambaran pengetahuan dan sikap orang tua dalam deteksi dini TB pada anak di wilayah kerja Puskesmas Kecamatan Rancaekek.

\section{METODE}

Rancangan penelitian yang digunakan yaitu deskriptif kuantitatif. Variabel yang diteliti adalah pengetahuan dan sikap terhadap deteksi dini TB pada anak yang meliputi tanda gejala TB anak, cara penularan dan faktor risiko kejadian TB anak. Jumlah populasi 128 pasien TB dewasa yang sedang menjalani pengobatan di wilayah keraja Puskesmas Kecamatan Rancaekek. Sampel direkrut dari seluruh populasi dengan teknik consecutive sampling menggunakan kriteria sampel orang tua penderita TB yang tinggal bersama anak usia 0-14 tahun dan sedang menjalani pengobatan, didapatkan sampel dengan jumlah 78 responden. Data dikumpulkan menggunakan kuesioner yang dibuat sendiri oleh peneliti dengan panduan dari Early Detection Of Tuberculosisdari WHO 2011dan buku Tuberkulosis Klinis dengan jumlah 15 pertanyaan pada variabel pengetahuan dan 15 pernyataan pada variabel sikap. Kuesioner sudah dilakukan content validity kepada ahli dibidangnya dan face validity serta construct validity kepada 15 
penderita TB dewasa di Rancaekek dengan nilai validitas ( $p$ value $>r$ tabel $=0,444$ ) dan nilai reliabilitas ( $r$ Alpha $=0,764>$ tabel). Hasil analisis data pengetahuan dimasukan kedalam kategori pengetahuan baik jika nilainya $\geq 75 \%$, kategori cukup jika nilainya $56 \%-74 \%$ dan kategori kurang jika nilainya $\leq 55 \%$. Variabe sikap dikatakan mendukung (favourable) jika

\section{HASIL PENELITIAN}

Hasil penelitian didapatkan data karakteristik demografi orang tua penderita TB serta pengetahuan dan sikap terhadap deteksi dini TB pada anak.

Tabel I Distribusi Frekuensi Karakteristik Demografi Orang Tua Penderita TB dan Karakteristik TB di Wilayah Kerja Puskesmas Kecamatan Rancaekek $(n=78)$

\begin{tabular}{lrr}
\hline \multicolumn{1}{c}{ Karakteristik } & $\mathrm{f}$ & $\%$ \\
\hline Usia & & \\
Dewasa awal (18-35) & 28 & 35,9 \\
Dewasa madya (36-55) & 39 & 50,0 \\
Dewasa akhir (56-65) & 11 & 14,1 \\
\hline Jenis Kelamin & & \\
Laki-laki & 38 & 48,7 \\
Perempuan & 40 & 51.3 \\
& & \\
\hline Pendidikan Terakhir & 11 & 14,1 \\
Tamat SD & 24 & 30,8 \\
SMP/Sederajat & 40 & 51,3 \\
SMA/Sederajat & 3 & 3,8 \\
Perguruan Tinggi & & \\
Mendapat Penyuluhan & & \\
Tentang Deteksi Dini TB & 52 & 66,7 \\
Sudah & 26 & 33,3 \\
Belum & & \\
Jenis Tuberkulosis & 24 & 30,8 \\
BTA negatif & 54 & 69,2 \\
BTA positif & & \\
Fase Pengobatan TB & 21 & 26,9 \\
Tahap Intensif & 57 & 73,1
\end{tabular}

Berdasarkan tabel I dapat diketahui bahwa dari 78 responden yang diteliti, setengah dari responden $(50,0 \%)$ berada di usia dewasa madya (36-55 tahun). Sebagian skor $T \geq 50$ dan tidak mendukung (unfavourable) jika skor $\mathrm{T} \leq 50$. Data dianalisis menggunakan distribusi frekuensi (Arikunto, 2013). Penelitian dilakukan di wilayah kerja Puskesmas Rancaekek, Puskesmas Linggar dan Puskesmas Nanjung Mekar dari bulan Juli hingga Agustus 2017.

besar dari responden berjenis kelamin perempuan $(51,3 \%)$, dan responden yang memiliki riwayat tingkat pendidikan terakhir sebagain besar responden pada jenjang SMA/sederajat sebanyak $(51,3 \%)$. Jenis TB responden, hampir seluruhnya dari responden dengan BTA positif $(69,2 \%)$. Pengalaman responden, sebagian besar dari responden $(66,7 \%)$ sudah pernah mendapatkan penyuluhan tentang deteksi dini TB dan $73,1 \%$ responden sudah dalam fase pengobatan tahap lanjutan.

\section{Tabel II Distribusi Frekuensi Pengetahuan Orang Tua Penderita TB tentang Deteksi Dini TB pada Anak di Wilayah Kerja Puskesmas Kecamatan Rancaekek ( $n=78)$}

\begin{tabular}{|c|c|c|c|c|c|c|}
\hline \multirow[t]{2}{*}{$\begin{array}{l}\text { Variabel } \\
\end{array}$} & \multicolumn{2}{|c|}{ Baik } & \multicolumn{2}{|c|}{ Cukup } & \multicolumn{2}{|c|}{ Kurang } \\
\hline & $\mathrm{F}$ & $\%$ & $f$ & $\%$ & $f$ & $\%$ \\
\hline $\begin{array}{l}\text { Pengeta } \\
\text { huan } \\
\text { Deteksi } \\
\text { Dini TB }\end{array}$ & 45 & $\begin{array}{r}57, \\
7\end{array}$ & 24 & $\begin{array}{r}30, \\
8\end{array}$ & 9 & 11,5 \\
\hline $\begin{array}{l}\text { Cara } \\
\text { Penular } \\
\text { an }\end{array}$ & 33 & $\begin{array}{r}42, \\
3\end{array}$ & 32 & $\begin{array}{r}41, \\
0\end{array}$ & 13 & 16,7 \\
\hline $\begin{array}{l}\text { Faktor } \\
\text { Risiko }\end{array}$ & 52 & $\begin{array}{r}66, \\
7\end{array}$ & 13 & $\begin{array}{r}16, \\
7\end{array}$ & 13 & 16,7 \\
\hline $\begin{array}{l}\text { Tanda } \\
\text { dan } \\
\text { Gejala }\end{array}$ & 47 & $\begin{array}{r}60, \\
3\end{array}$ & 22 & $\begin{array}{r}28, \\
2\end{array}$ & 9 & 11,5 \\
\hline
\end{tabular}

Berdasarkan tabel II dapat diketahui bahwa Komponen pengetahuan deteksi dini terhadap faktor risiko penularan TB ke anak sebagian besar responden dengan kategori baik $(57,7 \%)$, faktor resiko sebagian besar baik $(66,7 \%)$, tanda gejala TB pada anak sebagian besar dengan ketegori baik $(60,3 \%)$ dan cara penularan hampir setengah responden dengan kategori baik $(42,3 \%)$. 
Tabel III Distribusi Frekuensi Item Pertanyaan Pengatahuan Orang Tua Penderita TB tentang Deteksi Dini TB pada Anak di Wilayah Kerja Puskesmas Kecamatan Rancaekek ( $\mathrm{n}=78)$

\begin{tabular}{|c|c|c|c|c|c|c|}
\hline \multirow{2}{*}{ Komponen } & \multirow{2}{*}{$\begin{array}{l}\text { No } \\
\text { Soal }\end{array}$} & \multirow{2}{*}{ Pertanyaan } & \multicolumn{2}{|c|}{ Benar } & \multicolumn{2}{|c|}{ Salah } \\
\hline & & & $f$ & $\%$ & $f$ & $\%$ \\
\hline \multirow[t]{3}{*}{$\begin{array}{c}\text { Cara } \\
\text { Penularan }\end{array}$} & 3. & $\begin{array}{l}\text { Cara untuk menghindari } \\
\text { terhadap anak adalah, kecuali ? }\end{array}$ & 66 & 84,6 & 12 & 15,4 \\
\hline & 6. & $\begin{array}{l}\text { Berikut pernyataan yang benar mengenai } \\
\text { deteksi dini terhadap cara penularan TB } \\
\text { paru ke anak yaitu? }\end{array}$ & 52 & 66,7 & 26 & 33,3 \\
\hline & 11. & $\begin{array}{l}\text { Yang termasuk media penularan TB paru } \\
\text { adalah? }\end{array}$ & 56 & 71,8 & 22 & 28,2 \\
\hline \multirow[t]{6}{*}{$\begin{array}{l}\text { Faktor } \\
\text { Risiko }\end{array}$} & 1. & $\begin{array}{l}\text { Anak yang tinggal serumah dengan } \\
\text { penderita tuberkulosis (TB) paru tidak akan } \\
\text { tertular? }\end{array}$ & 77 & 98,7 & 1 & 1,3 \\
\hline & 8. & $\begin{array}{l}\text { Berikut merupakan faktor risiko kondisi } \\
\text { lingkungan yang dapat menyebabkan anak } \\
\text { tertular TB adalah? }\end{array}$ & 65 & 83,3 & 13 & 16,7 \\
\hline & 10. & $\begin{array}{l}\text { Anak akan mudah tertular TB apabila tidak } \\
\text { di berikan imunisasi. }\end{array}$ & 54 & 69,2 & 24 & 30,8 \\
\hline & 12 & $\begin{array}{l}\text { Lingkungan rumah yang baik untuk } \\
\text { mengurangi risiko kejadian TB paru pada } \\
\text { anak adalah }\end{array}$ & 56 & 71,8 & 22 & 28,2 \\
\hline & 14 & $\begin{array}{l}\text { Yang dapat menurunkan resiko penularan } \\
\text { penyakit TB paru ke anak adalah }\end{array}$ & 47 & 60,3 & 31 & 39,7 \\
\hline & 15 & $\begin{array}{l}\text { Status gizi anak dapat mempengaruhi } \\
\text { kejadian TB pada anak? }\end{array}$ & 67 & 85,9 & 11 & 14,1 \\
\hline \multirow[t]{4}{*}{$\begin{array}{l}\text { Tanda } \\
\text { Gejala }\end{array}$} & 2. & $\begin{array}{l}\text { Berikut merupakan gejala TB paru pada } \\
\text { anak? }\end{array}$ & 64 & 82,1 & 14 & 17,9 \\
\hline & 4. & $\begin{array}{l}\text { Apa gejala TB pada anak yang anda } \\
\text { ketahui? }\end{array}$ & 67 & 85,9 & 11 & 14,1 \\
\hline & 5. & $\begin{array}{l}\text { Anak demam dalam jangka lama, sering } \\
\text { berkeringat pada malm hari dan badan } \\
\text { terlihat lemah, gejala penyakit apakah } \\
\text { gejala-gejala tersebut? }\end{array}$ & 67 & 85,9 & 11 & 14,1 \\
\hline & 7. & $\begin{array}{l}\text { Terdapat benjolan di sekitar leher, ketiak } \\
\text { atau di area selangkangan pada anak, } \\
\text { pernyataan tersebut merupakan gejala dari }\end{array}$ & 56 & 71,8 & 22 & 28,2 \\
\hline
\end{tabular}




\begin{tabular}{|c|c|c|c|c|c|c|}
\hline \multirow{2}{*}{ Komponen } & \multirow{2}{*}{$\begin{array}{l}\text { No } \\
\text { Soal }\end{array}$} & \multirow{2}{*}{ Pertanyaan } & \multicolumn{2}{|c|}{ Benar } & \multicolumn{2}{|c|}{ Salah } \\
\hline & & & $f$ & $\%$ & $f$ & $\%$ \\
\hline & & TB ? & & & & \\
\hline & 9. & $\begin{array}{l}\text { Berikut merupakan salah satu dari gejala } \\
\text { TB pada anak sebagai deteksi dini adalah } \\
\text { ? }\end{array}$ & 67 & 85,9 & 11 & 14,1 \\
\hline & 13 & $\begin{array}{l}\text { Batuk-batuk seperti apakah yang anda } \\
\text { ketahui pada anak yang terkena TB ? }\end{array}$ & 45 & 57,7 & 33 & 42,3 \\
\hline
\end{tabular}

Berdasarkan tabel III diatas menunjukkan Item pertanyaan yang paling banyak respondenmenjawab benar yaitu pada komponen faktor risiko soal no $1(98,7 \%)$ dan $42,3 \%$ responden menjawab salah pada komponen tanda gejala no 13 .

Tabel IV Distribusi Frekuensi Sikap Orang Tua Penderita TB tentang Deteksi Dini TB pada Anak di Wilayah Kerja Puskesmas Kecamatan Rancaekek $(n=78)$

\begin{tabular}{lrrrr}
\hline \multirow{1}{*}{ Variabel } & \multicolumn{2}{c}{ Unfavorable } & \multicolumn{2}{c}{ Favorable } \\
\cline { 2 - 5 } & $\mathrm{f}$ & $\%$ & $\mathrm{f}$ & $\%$ \\
\hline $\begin{array}{l}\text { Sikap Deteksi } \\
\text { Dini TB }\end{array}$ & 44 & 56,4 & 34 & 43,6 \\
\hline Cara Penularan & 49 & 62,8 & 29 & 37,2 \\
\hline Faktor Risiko & 44 & 56,4 & 34 & 43,6 \\
\hline Tanda dan & 47 & 60,3 & 31 & 39,7 \\
Gejala & & & & \\
\hline
\end{tabular}

Berdasarkan tabel IV dapat diketahui bahwa sikap orang tua yang menderita TB dalam deteksi dini TB pada anak, sebagian besar dari responden dengan sikap mendukung/favorable (56.4\%) dan responden dengan sikap tidak mendukung/unfavorable mencakup hampir setengahnya (43,6\%). Komponen sikap terhadap cara penularan sebagian besar responden dengan kategori mendukung $(62,8 \%)$, mengenai tanda gejala TB anak sebagian besar dengan kategori mendukung $(60,3 \%)$ dan faktor risiko sebagian besar dari responden dengan sikap mendukung $(56,4 \%)$. 
Tabel V Distribusi Frekuensi Pernyataan Sikap Orang Tua Penderita TB tentang Deteksi

Dini TB pada Anak di Wilayah Kerja Puskesmas Kecamatan Rancaekek ( $n=78)$

Pernyataan
Saya menderita TB, menurut saya
tidak perlu menutup mulut ketika
berbicara di hadapan anak
Saya penderita TB, maka harus
menutup mulut ketika batuk, karena menurut saya penularan TB melalui percikan dahak

Saya penderita TB, maka saya tidak akan bersentuhan dengan anak karena keringat dapat menularkan TB

Menurut saya, anak kontak serumah dengan penderita TB beresiko tertular, maka anak harus segera dilakukan tes tuberkulin

Menurut saya, anak harus di hindarkan dengan lingkungan perumahan yang padat dan kumuh, karena risiko tinggi tertular TB

Saya tinggal di tempat yang banyak penderita TB, menurut saya anak

\begin{tabular}{cccccccccc}
\multicolumn{2}{c}{ SS } & \multicolumn{2}{c}{$\mathrm{S}$} & \multicolumn{2}{c}{$\mathrm{R}$} & \multicolumn{2}{c}{ TS } & \multicolumn{2}{c}{ STS } \\
\hline $\mathrm{f}$ & $\%$ & $\mathrm{~F}$ & $\%$ & $\mathrm{f}$ & $\%$ & $\mathrm{f}$ & $\%$ & $\mathrm{f}$ & $\%$ \\
\hline
\end{tabular}

$\begin{array}{llllllllll}5 & 6,4 & 12 & 15,4 & 9 & 11,5 & 42 & 53,8 & 10 & 12,8\end{array}$

$\begin{array}{llllllllll}23 & 29,5 & 45 & 57,7 & 4 & 5,1 & 4 & 5,1 & 2 & 2,6\end{array}$ tidak perlu diberikan imunisasi BCG

$\begin{array}{llllllllll}14 & 17,9 & 50 & 64,1 & 3 & 3,8 & 11 & 14,1 & 0 & 0\end{array}$

Menurut saya rumah yang mewah tanpa ventilasi akan mengurangi risiko anak terkena TB.

Menurut saya, kebersihan peralatan makan tidak perlu dijaga dan anak makan bersama penderita TB dalam satu alat makan.

Kejadian TB semakin tinggi, maka menurut saya status gizi pada anak $\begin{array}{llllllllll}21 & 26,9 & 43 & 55,1 & 0 & 0 & 12 & 15,4 & 2 & 2,6\end{array}$ $\begin{array}{llllllllll}1 & 1,3 & 5 & 6,4 & 4 & 5,1 & 47 & 60,3 & 21 & 26,9\end{array}$ harus sangat diperhatikan

Anak sering berkeringat berlebih pada malam hari, menurut saya hal itu bukan gejala penyakit apapun, maka tidak perlu dilakukan pemeriksaan 


\begin{tabular}{|c|c|c|c|c|c|c|c|c|c|c|}
\hline \multirow{2}{*}{ Pernyataan } & \multicolumn{2}{|c|}{ SS } & \multicolumn{2}{|c|}{$\mathrm{S}$} & \multicolumn{2}{|c|}{$\mathrm{R}$} & \multicolumn{2}{|c|}{ TS } & \multicolumn{2}{|c|}{ STS } \\
\hline & $f$ & $\%$ & $F$ & $\%$ & $f$ & $\%$ & $f$ & $\%$ & $f$ & $\%$ \\
\hline
\end{tabular}

Anak saya setiap hari sering terlihat kelelahan menurut saya sangat perlu anak segera di bawa ke pelayanan kesehatan untuk di periksa TB karena terdapat gejala

$\begin{array}{llllllllll}13 & 16,7 & 53 & 67,9 & 2 & 2,6 & 9 & 11,5 & 1 & 1,3\end{array}$

Anak saya demam sudah 3 minggu, saya tidak harus berkonsultasi dengan petugas kesehatan dan tidak mencari pengobatan

Teraba benjolan di area leher anak saya, saya meyakini bahwa anak terkena penyakit TB maka segera membawa ke pengobatan tradisional

$\begin{array}{llllllllll}0 & 0 & 5 & 6,4 & 2 & 2,6 & 39 & 50,0 & 32 & 41,0\end{array}$

Anak saya mengalami nyeri dada dan sesak nafas, perlu sebagai orang tua memeriksakan anak ke $\begin{array}{llllllllll}14 & 17,9 & 52 & 66,7 & 3 & 3,8 & 5 & 6,4 & 4 & 5,1\end{array}$ puskesmas terdekat secepatnya

Anak batuk lama menurut saya segera dibawa ke puskesmas untuk dilakukan tes tuberkulin

$\begin{array}{llllllllll}3 & 3,8 & 8 & 10,3 & 5 & 6,4 & 45 & 57,7 & 17 & 21,8\end{array}$

\section{PEMBAHASAN}

Pengetahuan Orang Tua Penderita TB dalam Deteksi Dini TB pada Anak.

Hasil penelitian didapatkan sebesar $57,7 \%$ responden dengan pengetahuan kategori baik, 30,8\% dengan kategori cukup dan $11,5 \%$ dengan kategori kurang. Hal ini dapat digambarkan bahwa sebagian besar orang tua yang menderita TB sudah mengetahui tentang deteksi dini TB pada anak. Melihat komponen pertanyaan tentang faktor risiko sebagian besar dari responden dalam kategori baik $(66,7 \%)$, dilihat dari analisis setiap item pertanyaan 98,7\% menjawab pertanyaan benar mengenai risiko penularan terhadap anak yang tinggal bersama penderita TB. Nevita, Sutomo dan Triasih (2014) mengemukakan bahwa anak yang kontak serumah dengan penderita TB mempunyai risiko lebih tinggi untuk sakit TB yaitu 25-70\%. Selain itu, pertanyaan mengenai tanda gejala yang menunjukkan sebagian besar dari responden berada pada pengetahuan kategori baik (60,3\%), sebagian besar orang tua yang menderita TB sudah mengetahui tentang tanda gejala TB pada anak, hal ini kemungkinan didukung dengan pengalaman pribadi responden seperti dalam tahap pengobatan responden sering mendapatkan informasi terkait TB terutama tetang gejala pada anak, reponden yang pengetahuannya dengan ketegori baik $43,6 \%$ diantaranya responden yang sedang menjalani pengobatan pada tahap lanjutan.

Pengetahuan baik juga didapat dari faktor pengalaman responden sebagian besar sudah pernah mendapatkan pendidikan kesehatan dari petugas Puskesmas maupun dari kader kesehatan setempat $(66,7 \%)$. Hampir setengah dari responden (38,5\%) dengan pengetahuan kategori baik diantaranya yang sudah pernah mengikuti penyuluhan. Sesuai dengan penelitian Sukana, Herryanto dan Supraptini (2003) bahwa ada pengaruh dari kegiatan penyuluhan terhadap pengetahuan, dari hasil penelitiannya di dapatkan hasil yang signifikan pengetahuan responden tentang TB 
sebelum dan sesudah mengikuti penyuluhan. Seperti dalam teori bahwa pengetahuan seseorang dapat diperoleh dari pengalaman seseorang itu sendiri yang nantinya akan menjadi sumber informasi sehingga dapat berpengaruh terhadap pengetahuannya (Notoatmodjo, 2012).

Meskipun sebagian besar pengetahuan responden dalam kategori baik, akan tetapi hasil penelitian ini masih terdapat sebagian kecil dari responden dengan pengetahuan kategori cukup dan kurang. Pengetahuan dengan kategori cukup dan kurang melihat dari hasil hampir setengah dari responden dengan kategori baik $(42,3 \%)$ dan $41,0 \%$ responden dengan kategori kurang tentang cara penularan TB pada anak, sehingga dapat dilihat hasilnya tidak terdapat perbedaan yang cukup signifikan antara responden dengan pengetahuan kategori baik dengan kategori kurang. Hasil analisis dari setiap item pertanyaan sebagian besar dari responden $(33,3 \%)$ menjawab salah, yaitu sebagian besar responden menjawab cara penularan TB dapat melalui keringat atau berjabat tangan langsung dengan anak. Salah satu faktor kemungkinan pengalaman responden dalam mengikitu pendidikan kesehatan, pada data penelitian hampir dari setengah responden dengan pengetahuan kategori cukup terhadap cara penularan yaitu $30,8 \%$ diantarnya responden yang sudah pernah mendapatkan pendidikan kesehatan, hal ini kemungkinan responden hanya memahami sebagian komponen terkait TB. Melihat persentase dan hasil tersebut sebagian besar orang tua penderita TB kurang mengetahui terhadap cara penularan TB pada anak.

\section{Sikap Orang Tua Penderita TB dalam Deteksi Dini TB pada Anak}

Hasil penelitian didapatkan sebesar $56,4 \%$ berada pada kategori mendukung (favourable). Responden dengan kategori tidak mendukung (unfavorable) mencakup hampir setengah dari responden sebanyak $43,6 \%$. Hal ini dapat digambarkan bahwa sebagian besar dari responden berada pada kategori mendukung terhadap deteksi dini TB pada anak. Sikap orang tua yang mendukung, pada dasarnya pengetahuan orang tua yang sebagian besar berada dalam kategori baik.
Pengetahuan itu sendiri adalah titik tolak perubahan sikap (Notoatmodjo, 2012). Melihat dari pernyataan cara penularan sebagian besar yaitu $62,8 \%$ responden dengan sikap mendukung (favorable), dilihat dari hasil analisis item pernyataan 57,7\% dengan sikap mendukung terhadap keharusan menutup mulut pada saat batuk dan berbicara dihadapan anak langsung, sebagian besar responden menjawab setuju. Selain itu, lebih dari setengah responden dengan kategori sikap mendukung terhadap gejala TB pada anak $(60,3 \%)$, dilihat dari hasil analisis item pernyataan $66,7 \%$ responden menjawab setuju terhadap gejala yang timbul ketika anak mengeluh nyeri dada dan sesak nafas, menurut responden segera anak dibawa ke pelayanan kesehatan untuk diperiksa kesehatannya terutama pemeriksaan TB.

Total responden sebagian besar yang menjalani pengobatan dalam tahap lanjutan, pasien dengan pengobatan tahap lanjutan tentunya mepunyai informasi lebih luas terkait TB salah satunya tentang deteksi dini TB pada anak, karena menurut data yang didapatkan bahwa petugas kesehatan TB memberikan pendidikan kesehatan sederhana yaitu dengan metode ceramah ketika responden berkunjung pengambilan obat, sehingga informasi yang didapat lebih banyak kemudian dapat membentuk sikap yang positif atau mendukung, namun tidak seluruhnya responden dapat membentuk sikap mendukung. Hal ini sejalan dengan yang dikemukakan oleh Azwar (2014) bahwa seseorang yang memiliki pengalaman terhadap suatu objek, maka hal tersebut akan mendorong seseorang dalam membentuk sikap yang positif atau mendukung terhadap objek tersebut. Hasil penelitian Palupi (2014) menyatakan bahwa dari 35 responden sebagian besar dengan sikap positif setelah diberikan pendidikan kesehatan dari 14,3\% menjadi $38,0 \%$ setelah diberikan penyuluhan.

Meskipun sebagian besar dari responden dalam kategori mendukung (favourable), akan tetapi hampir setengah dari responden dengan kategori tidak mendukung (unfavorabel) terhadap deteksi dini $(43,6 \%)$. $\mathrm{Hal}$ ini kemungkinan kurangnya kemampuan orang tua dalam menggunakan pengetahuannya yang sudah diperoleh. 
Seperti pada komponen faktor risiko sebagian besar responden dengan kategori pengetahuan baik, akan tetapi hampir setengah dari responden dengan kategori sikap tidak mendukung terhadap faktor risiko $(43,6 \%)$, hasil analisis dari beberapa item didapatkan $23,1 \%$ sikap tidak mendukung terhadap kebersihan peralatan makan terhadap anak. Menurut Azwar (2014) faktor yang mempengaruhi sikap diantaranya pengalaman pribadi, pengaruh orang lain yang dianggap penting, kebudayaan, media massa, lembaga pendidikan dan emosional. Selain itu, pengetahuan yang baik pada responden maka akan terbentuk sikap yang mendukung yang merupakan faktor internal pada diri responden/orang tua, namun tidak hanya faktor internal, terbentuknya sikap dapat juga dipenguruhi oleh faktor lain.

\section{SIMPULAN DAN SARAN}

Simpulan dalam penelitian ini antara lain:

1. Sebagian besar orang tua sudah mengetahui tentang deteksi dini dengan kategori baik. Berdasarkan komponen pengetahuan bahwa frekuensi tentang faktor risiko dan tanda gejala TB pada anak lebih banyak dengan kategori baik dibandingkan dengan tentang cara penularan TB. Meskipun sebagian besar dalam kategori baik, akan tetapi hampir setengah dari orang tua penderita TB yang menjadi responden berada dalam pengetahuan kategori cukup dan sebagian kecil dalam pengetahuan kategori kurang terutama pada komponen pengetahuan cara penularan TB

2. Sebagian besar orang tua bersikap mendukung (favorable) terhadap deteksi dini TB pada anak, akan tetapi hampir setengahnya dari orang tua penderita TB di wilayah kerja Puskesmas Rancaekek bersikap tidak mendukung terhadap deteksi dini TB pada anak. Berdasarkan komponen sikap menunjukkah bahwa tentang cara penularan TB dan tanda gejala TB pada anak lebih banyak orang tua bersikap mendukung dibandingkan dengan faktor risiko penularan TB.
Saran :

1. Saran bagi petugas Puskesmas dan bagi para kader kesehatanagar melakukan pendidikan kesehatan yang tidak hanya berpusat kepada aspek kognitif saja, akan tetapi mencakup aspek kognitif (pengetahuan) dan afektif (sikap), terutama kepada orang tua penderita TB dengan kategori pengetahuan cukup dan kurang serta kategori sikap tidak mendukung dalam deteksi dini pada anak.

2. Melakukan kegiatan pendidikan kesehatan dapat dilakukan dengan cara home visit, yang berupa pemberian pendidikan kesehatan lanjutan yang sudah diberikan di Puskesmas,dengan kegitan home visit ini petugas kesehatan juga akan mendapatkan informasi terhadap perkembangan pengetahuan, sikap dan kesehatan penderita TB dan keluarga serta dapat menjalankan upaya kesehatan dan membantu keluarga mencapai tingkat kemandirian. Selain itu, kegiatan home visit dapat juga memberikan konseling, direct care dan pelibatan keluarga.

3. Orang tua dengan kategori pegetahuan baik dapat diberikan motivasi untuk terus meningkatkan dan mengaplikasikan pengetahuannya dalam kehidupan sehari hari sehingga orang lain dapat meniru sikap ibu tersebut.

4. Peneliti menyarankan untuk melakukan penelitian lanjutan mengenai faktor-faktor yang dapat mempengaruhi pengetahuan dan sikap orang tua terhadap deteksi dini TB pada anak.

5. Peneliti menyarankan untuk melakukan penelitian tidak hanya kepada orang tua yang menderita TB saja, akan tetapi kepada seluruh orang tua.

\section{DAFTAR PUSTAKA}

Arikunto, S. (2013). Prosedur Penelitian Suatu Pendekatan Paraktik. Jakarta: Rineka Cipta.

Azwar, S. (2014). Sikap Manusia Teori dan Pengukurannya. Yogyakarta: Pustaka Pelajar 
Bati, J., Legesse, M., \& Medhin, G. (2013). Community's knowledge, attitudes and practices about tuberculosis in Itang Special District, Gambella Region, South Western Ethiopia. BioMed Central Public Health, 2-9. doi:10.1186/1471-2458-13-734

Crofton, J., Horne, N., \& Miller, F. (2002). Tuberkulosis Klinis. Jakarta: Widya Medika.

Guwatudde, D. (2003). Tuberculosis in Household Contacts of Infectious Cases in Kampala, Uganda. American Journal of Epidemiology, 158

Kemenkes RI. (2015). Infodatin Pusat Data dan Informasi Kementrian Kesehatan RI. Jakarta: Kemenkes RI. Diambil kembali dari http://www.depkes.go.id/resources/download/ pusdatin/infodatin/infodatin_tb.pdf

Kemenkes RI. (2013). Petunjuk Teknis Manajemen TB Anak. Jakarta. Diambil kembali dari spiritia.or.id/dokumen/juknistbanak2013.pdf

Loeffler, A. (2003). Pedriatric Tuberculosis. Elsevier Inc, 18. Diambil kembali dari http://www.ohsu.edu/

Manalu, H. S., \& Sukana, B. (2011). Aspek Pengetahuan Sikap dan Perilaku Masyarakat Kaitannya Dengan Penyakit Tb paru. Media Litbang Kesehatan, 21, 39-46. Diambil kembali dari ejournal.litbang.depkes.go.id/index.php/MPK/ article/download/114/95

Nevita, Sutomo, R., \& Triasih, R. (2014). Faktor Resiko Kejadian Tuberkulosis Laten pada Anak Kontak Serumah dengan Tuberkulosis Dewasa. Sari Pediatri, no 1, 510

Noviyani, E., Fatimah, S., Nurhidayah, I., \& Adistie, F. (2015, Agustus). Upaya Pencegahan Penularan TB dari Dewasa terhadap Anak. 3, 97-103. Diambil kembali dari

http://jkp.fkep.unpad.ac.id/index.php/jkp/article /download/105/10
Notoatmodjo, S. (2012). Promosi Kesehatan dan Perilaku Kesehatan. Jakarta: Rineka Cipta.

Palupi, D. L. (2014). Pengaruh Pendidikan Kesehatan Terhadap Perubahan Pengalaman, Sikap dan Perilaku Penderita Tuberkulosis yang berobat di Wilayah Kerja Puskesmas Surakarta. Jurnal Keperawatan, 2.

Stop TB Partnership. (2015). The Global Plan to End TB 2016-2020: The Paradigm Shift. Geneva, Switzerland: Stop TB Partnership. UNOPS.

Sudiantara, K., Wahyuni, N. S., \& Harini, I. (2014, Desember). Faktor-faktor Yang Mempengaruhi Peingkatan Kasus TB Paru. Jurnal GEMA KEPERAWATAN.

Sukana, B., Herryanto, \& Supraptini. (2003). Pengaruh Penuluhan Terhadap Pengetahuan Penderita TB paru di Kabupaten Tangerang. Jurnal Ekologi Kesehatan, 2. Diambil kembali dari

http://ejournal.litbang.depkes.go.id/index.php/j ek/article/view/5399/4427

World Health Organization. (2011). Early Detection of Tuberculosis.

World Health Organization. (2015). Global Tuberculosis Report 2015. Avenue appia, Geneva, Switzerland: WHO the Global TB Programe. Diambil kembali dari http://www.who.int/tb/publications/global_repo rt/gtbr15_main_text.pdf. 